\title{
Uji Potensi Ekstrak Daun Putri Malu (Mimosa pudica Linn) yang Tumbuh di Padang sebagai Larvasida Nabati terhadap Mortalitas Larva Nyamuk Aedes aegypti
}

\author{
Vannisa Al Khalish ${ }^{1}$, Nora Harminarti ${ }^{2}$, Yusticia Katar ${ }^{3}$
}

\begin{abstract}
Abstrak
Demam Berdarah Dengue (DBD) disebabkan oleh virus dengue melalui vektor penular utama yaitu nyamuk betina Aedes aegypti. Salah satu upaya pemberantasan vektor penular tersebut adalah larvasida sintetik, namun dapat menyebabkan resistensi vektor dan pencemaran lingkungan. Ekstrak daun putri malu dapat dijadikan alternatif sebagai larvasida nabati. Tujuan: Menentukan pengaruh pemberian ekstrak daun putri malu (Mimosa pudica Linn.) yang tumbuh di Padang terhadap mortalitas larva nyamuk Aedes aegypti. Metode: Penelitian ini adalah studi eksperimental laboratorium dengan rancangan acak lengkap yang terdiri dari delapan perlakuan dan satu kontrol dengan $4 \mathrm{x}$ pengulangan. Penelitian ini dilaksanakan di Laboratorium Farmasi dan Laboratorium Parasitologi Universitas Andalas. Sampel terdiri dari 720 ekor larva Aedes aegypti instar III/IV. Setiap kelompok uji berisi 20 ekor larva dalam $200 \mathrm{ml}$ larutan (ekstrak + akuades) dengan serial konsentrasi ekstrak 1, 2, 3, 4, 5, 10, 12,5, dan $15 \mathrm{mg} / \mathrm{ml}$. Jumlah kematian larva dicatat setelah 24 jam pemaparan ekstrak. Hasil: Ekstrak daun putri malu yang dengan konsentrasi ekstrak 1, 2, 3, 4, dan $5 \mathrm{mg} / \mathrm{ml}$ tidak efektif sebagai larvasida, sedangkan konsentrasi 10, 12,5 dan 15 $\mathrm{mg} / \mathrm{ml}$ efektif sebagai larvasida dengan persentase kematian masing-masing adalah $12,5,30$, dan $60 \%$. Nilai LC $\mathrm{C}_{50}$ ekstrak daun putri malu adalah $14,568 \mathrm{mg} / \mathrm{ml}$. Simpulan: Ekstrak daun putri malu yang tumbuh di Padang berpotensi sebagai larvasida Aedes aegypti.
\end{abstract}

Kata kunci: Aedes aegypti, larvasida nabati, Mimosa pudica Linn

\section{Abstract}

Dengue Hemorrhagic Fever (DHF) is a disease caused by the dengue virus through the main vector, the female mosquito of Aedes aegypti. The method to eradicate mosquito larvae is synthetic larvicides but could cause vector resistance and environmental pollution. Mimosa leaves extract is an alternative to phyto-larvicides. Objectives: To determined the effect of the mimosa leaves extract (Mimosa pudica Linn), which grows in Padang on the mortality of mosquito larvae (Aedes aegypti). Methods: This study was an experimental laboratory with a completely randomized design consisted of eight treated group and one control group with four times replication. This study was conducted at the Pharmacy Laboratory and Parasitology Laboratory of Andalas University. The samples consisted of seven hundred twenty instar III/IV larvae of Aedes aegypti. Each test group contained 20 larvae in $200 \mathrm{ml}$ of solution (extract + aquades) with serial concentrations $1,2,3,4,5,10,12,5$, and $15 \mathrm{mg} / \mathrm{ml}$. The number of mortality of larvae was recorded after 24 hours of extract exposure. Results: The mimosa leaves extract in 1, 2, 3, 4, and $5 \mathrm{mg} / \mathrm{m} /$ were not effective as a larvicide, meanwhile, in 10,12,5 and $15 \mathrm{mg} / \mathrm{ml}$ were effective as larvicide which the mortality percentage for each are 12,5, 30, and 60\%. LC 50 of mimosa leaves extract is $14,568 \mathrm{mg} / \mathrm{ml}$. Conclusion: The mimosa leaves (Mimosa pudica Linn) extract, which grows in Padang, has the potential to be the phyto-larvicide of Aedes aegypti.

Keywords: DHF, Aedes aegypti, phyto-larvicide, Mimosa pudica Linn

Affiliasi penulis: ${ }^{1}$ Prodi Kedokteran, Fakultas Kedokteran, Universitas

Andalas, Padang, Indonesia. ${ }^{2}$ Bagian Parasitologi, Fakultas Kedokteran, Universitas Andalas, Padang, Indonesia. ${ }^{3}$ Bagian
Farmakologi, Fakultas Kedokteran, Universitas Andalas, Padang, Indonesia.

Korespondensi: Nora Harminarti, Email:

noraharminarti@med.unand.ac.id Telp: 085216270291 


\section{PENDAHULUAN}

Insiden Demam Berdarah Dengue (DBD) di seluruh dunia dalam 50 tahun terakhir terus mengalami peningkatan, diperkirakan 50 juta kasus terjadi setiap tahun dan setengah miliar atau dua perlima penduduk dunia berisiko terserang penyakit tersebut. DBD adalah masalah kesehatan masyarakat yang utama di negara Indonesia, Myanmar, Sri Lanka, Thailand dan Timor-Leste yang merupakan negara tropis dan berada pada garis khatulistiwa dimana terdapat penyebaran Aedes aegypti yang luas. ${ }^{1}$

Berdasarkan data Dinas Kesehatan Provinsi Sumatera Barat tahun 2016, angka prevalensi DBD di Kota Padang memiliki nilai tertinggi dibandingkan dengan kabupaten/ kota lainnya di Sumbar yaitu 1.074 kasus selama tahun 2015. Dari 11 kecamatan di Kota Padang, Kecamatan Kuranji menjadi daerah dengan kasus DBD tertinggi yaitu 168 kasus di tahun 2015 dan 201 kasus di tahun 2016 dan kasus terendah terdapat di Kecamatan Bungus dengan 11 kasus di tahun 2015 dan 20 kasus di tahun 2016. ${ }^{2}$

Mikroorganisme penyebab penyakit infeksi tersebut adalah virus dengue, dengan Aedes aegypti (Ae. aegypti) sebagai vektor penular utamanya, meskipun vektor penyakit tersebut dapat pula berasal dari berbagai spesies Aedes sp. lainnya. ${ }^{3}$

Pengendalian Vektor Terpadu/ PVT (Integrated Vektor Management) memiliki tiga intervensi utama, yakni intervensi secara kimiawi, biologis, dan mekanik (fisik atau pengelolaan lingkungan). ${ }^{4}$ Salah satu contoh pengendalian vektor secara kimiawi adalah dengan menggunakan insektisida terhadap nyamuk dewasa dan larvasida terhadap larva. Penggunaan insektisida secara intensif dalam jangka waktu yang lama atau terus menerus dalam mengontrol nyamuk vektor DBD mungkin dapat menyebabkan resistensi vektor dan menjadi salah satu penyebab terjadinya peningkatan kasus DBD di suatu wilayah.

Tumbuhan putri malu (Mimosa pudica Linn.) merupakan salah satu tumbuhan yang dapat dijadikan sebagai pengganti larvasida sintetik. Tumbuhan tersebut mengandung beberapa senyawa aktif dari golongan polifenol yaitu alkaloid, flavonoid, tanin dan saponin. ${ }^{5}$ Daun putri malu memiliki konsentrasi senyawa aktif terbesar secara signifikan dibandingkan bagian lain, yaitu akar, batang, dan bunga. ${ }^{6,7}$
Penelitian sebelumnya tentang ekstrak daun putri malu sebagai larvasida sudah pernah dilakukan oleh Fitria dan Amilah pada tahun 2015 di Surabaya. Hasil penelitian tersebut didapatkan bahwa daun putri malu (Mimosa pudica L.) terbukti mampu meningkatkan kematian larva nyamuk demam berdarah Aedes aegypti dengan konsentrasi letal 3,25 g/l air. ${ }^{8}$ Penelitian yang dilakukan oleh Astalakshmi et al pada tahun 2016 dengan menggunakan sampel tanaman putri malu yang berasal dari kota Chelembra, India, didapatkan hasil bahwa ekstrak daun putri malu dengan serial konsentrasi $250,500,750,1.000$, dan $2.000 \mu \mathrm{g} / \mathrm{ml}$ kurang efektif sebagai larvasida karena potensinya yang lemah sehingga membutuhkan konsentrasi ekstrak yang lebih tinggi. ${ }^{9}$ Hal yang mempengaruhi hasil penelitian tersebut selain karena besarnya konsentrasi yang digunakan juga mungkin dipengaruhi oleh faktor faktor ekologi.

Faktor ekologi memiliki pengaruh yang signifikan terhadap konsentrasi bahan aktif, namun tidak pada jenis bahan aktifnya. Faktor ekologi utama yang mempengaruhi kandungan bahan aktif suatu tumbuhan adalah curah hujan, suhu, durasi sinar matahari, $\mathrm{pH}$ tanah, bahan organik, dan kalium yang tersedia di suatu tempat. ${ }^{10}$ Faktor tersebut dapat menyebabkan kandungan metabolit dari suatu tumbuhan bervariasi dan aktivitas farmakologi yang dihasilkan berbeda-beda.

\section{METODE}

Jenis penelitian ini adalah studi eksperimental laboratorium dengan Rancangan Acak Lengkap (Completely Randomized Design) yang terdiri dari 8 perlakuan dan 1 kontrol dengan pengulangan sebanyak 4 kali. ${ }^{11}$ Penelitian dilaksanakan di Laboratorium Parasitologi Fakultas Kedokteran Universitas Andalas (Unand), Padang. Hewan uji berupa larva Ae. Aegypti instar III atau IV yang ditetaskan dari telur. Telur tersebut diperoleh menggunakan ovitrap di Kelurahan Korong Gadang, Kecamatan Kuranji, Kota Padang. Pemilihan tempat tersebut karena berdasarkan penelitian yang telah dilakukan oleh Nofita et al pada tahun 2017 di Padang, kelurahan tersebut memiliki risiko demam berdarah tertinggi dibandingkan kelurahan lainnya. ${ }^{12}$ Daun putri malu diperoleh dari Kebun Tanaman Obat (KTO) 
Universitas Andalas (Unand) dan pembuatan ekstrak dilakukan di Laboratorium Farmakologi Fakultas Farmasi Unand.

Pelaksanaan penelitian di mulai pada bulan MeiDesember 2018, mulai dari penyusunan proposal hingga menyelesaikan penelitian. Populasi penelitian ini adalah larva nyamuk Ae. aegypti instar III atau IV yang diperoleh dari telur yang diambil di Kelurahan Korong Gadang, Kecamatan Kuranji, Kota Padang. ${ }^{12}$

Metode pengambilan sampel pada penelitian ini adalah non-random (non-probability) sampling dengan teknik purposive sampling terhadap larva Aedes aegypti. Besar sampel dalam penelitian ini adalah 720 ekor larva Ae. aegypti instar III atau IV. Berdasarkan pedoman WHO tentang pengujian larvasida terhadap larva, setiap kelompok perlakuan membutuhkan larva sebanyak 20 ekor. $^{11}$ Kriteria inklusi larva: larva Ae. aegypti yang telah mencapai instar III atau IV dan bergerak aktif. Kriteria eksklusi larva: larva Ae. aegypti yang telah berubah menjadi pupa ataupun nyamuk dewasa dan larva yang mati sebelum perlakuan.

Penentuan spesies larva dengan single-larva method, untuk memastikan larva yang digunakan merupakan Ae. aegypti maka dilakukan identifikasi sampel dan pengukuran larva menggunakan mikroskop berdasarkan pedoman Atlas Parasitologi Kedokteran. ${ }^{13}$

Larva dipelihara berdasarkan kondisi yang disarankan oleh WHO (2016) agar larva dapat tumbuh dengan sehat dan baik, yaitu pada lingkungan dengan suhu ruangan $25 \pm 2^{\circ} \mathrm{C},{ }^{11}$ temperatur air antara $25-28^{\circ} \mathrm{C}$ dan $\mathrm{pH}$ air $7 .^{14}$ Makanan yang diberikan kepada larva berupa pelet ikan yang digerus halus dan diberikan dengan interval satu atau dua hari sekali. ${ }^{11}$

Prosedur pembuatan ekstrak mengacu pada penelitian Fitria dan Amilah S pada tahun 2015, yaitu daun putri malu (Mimosa pudica Linn.) dicuci dan dikeringkan dengan cara diangin-anginkan, lalu dihaluskan. Simplisia serbuk sebanyak 300 gr diekstraksi dengan cara maserasi yaitu merendam sampel dalam 3 liter pelarut etanol 96\% dengan perbandingan berat simplisia (gr) dengan volume pelarut (ml) 1:10 pada botol gelap selama 2-3 hari. ${ }^{8}$ Ekstrak tersebut kemudian disaring untuk memisahkan antara residu dan filtratnya. Hasil filtrat kemudian dipekatkan dengan menggunakan Rotary Evaporator
(RE) sehingga dihasilkan crude extract. Hasil akhir ekstrak kental ditimbang dengan menggunakan timbangan elektrik dan didapatkan hasil sebanyak 45 gram, kemudian diletakan ke dalam tabung dan disimpan di tempat yang sejuk.

Uji potensi ekstrak dilakukan dengan menggunakan gelas plastik berukuran $250 \mathrm{ml}$ sebanyak 36 buah untuk 9 perlakuan dengan pengulangan sebanyak 4 kali. Proses pembuatan larutan induk ekstrak daun putri malu konsentrasi 20 $\mathrm{mg} / \mathrm{ml}$ dengan memasukan ekstrak kental daun putri malu sebanyak 44 gram ke dalam 2.200 ml akuades, kemudian larutan tersebut diencerkan sehingga didapatkan larutan dengan konsentrasi 1, 2, 3, 4, 5, $10,12,5$ dan $15 \mathrm{mg} / \mathrm{ml}$ serta akuades sebagai kontrol. Masukan larva ke dalam gelas tersebut masingmasing 20 ekor untuk tiap gelas. Amati efek yang diberikan ekstrak daun putri malu setelah 24 jam pemaparan. $^{11}$

Hitung larva yang mati dan hampir mati (moribund) ke dalam perhitungan persentasi kematian. Larva mati adalah larva yang tidak dapat bergerak meskipun sudah distimulasi dengan batang pengaduk atau lidi di daerah sifon-nya. Larva hampir mati (moribund) ditandai dengan larva yang tidak mampu lagi berenang ke permukaan atau tidak menunjukkan reaksi menyelam ke dasar wadah ketika airnya diganggu. $^{11}$

Data hasil kematian larva Aedes aegypti akibat pemaparan ekstrak daun putri malu (Mimosa pudica Linn.) tiap unit uji dihitung dengan menggunakan rumus:

Persentase Kematian

$=($ Jumlah larva mati / jumlah larva uji $) \times 100 \%$

Dengan ketentuan sebagai berikut: ${ }^{11}$

1. Jika kematian larva pada kelompok kontrol kurang dari 5\% maka diabaikan

2. Jika lebih dari $20 \%$ maka di uji ulang

3. Jika antara 5-20\% maka angka kematian larva nyamuk pada masing-masing konsentrasi harus di koreksi dengan formula Abbott, yaitu:

$$
M=((T-C) /(100-C)) \times 100 \%
$$

Keterangan:

M : Angka kematian setelah koreksi (\%)

$\mathrm{T}$ : Angka kematian kelompok perlakuan (\%) 
C : Angka kematian kelompok kontrol (\%)

Data yang diperoleh dilakukan uji normalitas data dengan Shapiro-Wilk Test. Data dengan distribusi normal dilanjutkan dengan uji statistik One-Way ANOVA dan Post Hoc LSD, jika hasil tidak homogen dilakukan uji Kruskal-Wallis dan dilanjutkan dengan uji signifikansi Mann-whitney. Parameter yang akan diuji meliputi konsentrasi dan mortalitas. Hasil uji ANOVA akan dilanjutkan ke uji DMRT (Duchan's Multiple Range Test) apabila hasilnya berbeda nyata. Nilai LC50 didapatkan berdasarkan analisis jumlah kematian larva nyamuk Ae. Aegypti menggunakan analisis probit (Finney Method) dengan menggunakan aplikasi computer.

Penelitian ini sudah mendapatkan layak etik dari Komite Etik Penelitian Fakultas Kedokteran UNAND dengan No.044/KEP/FK/2019.

\section{HASIL}

Penelitian ini dilakukan terhadap 720 ekor larva Aedes aegypti dengan menggunakan konsentrasi ekstrak dau putri malu (Mimosa pudica Linn) 1, 2, 3, 4, $5,10,12,5$ dan 15 serta akuades sebagai kontrol.

\section{Hasil Uji Potensi Ekstrak Daun Putri Malu (Mimosa pudica Linn) yang Tumbuh di Padang terhadap Mortalitas Larva Nyamuk Aedes aegypti}

Pengamatan jumlah larva Aedes aegypti yang mati dan hampir mati (moribund) dilakukan setelah 24 jam pemaparan ekstrak. Hasil penghitungan yang diperoleh dapat dilihat pada tabel berikut:

Tabel 1. Pengaruh Ekstrak Daun Putri Malu (Mimosa pudica Linn.) pada konsentrasi 1, 2, 3, 4 dan $5 \mathrm{mg} / \mathrm{ml}$ terhadap Kematian Larva Aedes aegypti setelah 24 Jam Pemaparan.

\begin{tabular}{ccccccc}
\hline & \multicolumn{5}{c}{$\begin{array}{c}\text { Perlakuan dengan } \\
\text { Konsentrasi } \\
\text { (mg/ml) }\end{array}$} & Kontrol \\
\cline { 2 - 5 } & $\mathbf{1}$ & $\mathbf{2}$ & $\mathbf{3}$ & $\mathbf{4}$ & $\mathbf{5}$ & \\
\hline 1 & 0 & 0 & 0 & 0 & 0 & 0 \\
2 & 0 & 0 & 0 & 0 & 0 & 0 \\
3 & 0 & 0 & 0 & 0 & 0 & 0 \\
4 & 0 & 0 & 0 & 0 & 0 & 0 \\
\hline $\begin{array}{c}\text { Jumlah Kematian } \\
\text { (Ekor) }\end{array}$ & 0 & 0 & 0 & 0 & 0 & 0 \\
Rata-rata Kematian & 0 & 0 & 0 & 0 & 0 & 0 \\
$\quad$ (Ekor) & 0 & 0 & 0 & 0 & 0 & 0 \\
Persentase & & & & & & 0 \\
Kematian (\%) & & &
\end{tabular}

Berdasarkan Tabel 1 dapat dilihat bahwa tidak dijumpai kematian larva Aedes aegypti pada konsentrasi 1, 2, 3, 4, dan $5 \mathrm{mg} / \mathrm{ml}$ setelah pemaparan ekstrak selama 24 jam, sehingga peneliti melakukan percobaan kedua dengan menggunakan konsentrasi yang lebih tinggi yaitu $10,12,5$, dan $15 \mathrm{mg} / \mathrm{ml}$ untuk menemukan $L_{50}$ dari ekstrak daun putri malu (Mimosa pudica Linn). Hasil penghitungan yang diperoleh dapat dilihat pada tabel berikut:

Tabel 2. Pengaruh ekstrak daun putri malu (Mimosa pudica Linn.) pada konsentrasi 10, 12,5 dan $15 \mathrm{mg} / \mathrm{ml}$ terhadap Kematian Larva Aedes aegypti setelah 24 Jam Pemaparan.

\begin{tabular}{|c|c|c|c|c|}
\hline \multirow{3}{*}{ Pengulangan } & \multicolumn{4}{|c|}{ Perlakuan dengan } \\
\hline & \multicolumn{3}{|c|}{$\begin{array}{c}\text { Konsentrasi } \\
(\mathrm{mg} / \mathrm{ml})\end{array}$} & \multirow[t]{2}{*}{$\begin{array}{l}\text { Kon- } \\
\text { trol }\end{array}$} \\
\hline & 10 & 12,5 & 15 & \\
\hline 1 & 2 & 6 & 13 & 0 \\
\hline 2 & 4 & 6 & 12 & 0 \\
\hline 3 & 2 & 5 & 10 & 0 \\
\hline 4 & 2 & 7 & 13 & 0 \\
\hline Jumlah Kematian (Ekor) & 10 & 24 & 48 & 0 \\
\hline Rata-rata Kematian (Ekor) & 2,5 & 6 & 12 & 0 \\
\hline Persentase Kematian (\%) & 12,5 & 30 & 60 & 0 \\
\hline
\end{tabular}

Berdasarkan Tabel 2 dapat dilihat bahwa dijumpai kematian larva Aedes aegypti pada konsentrasi $10 \mathrm{mg} / \mathrm{ml}$ dengan nilai persentase kematian sebesar $12,5 \%$ dan tertinggi pada konsentarsi $15 \mathrm{mg} / \mathrm{ml}$ sebesar $60 \%$ dan sudah mencapai lebih dari 50\% kematian.

\section{Hasil Uji Analisis Probit}

Data yang sudah diperoleh dari Tabel 2 kemudian dianalisis dengan metode analisis probit untuk mengetahui LC50 ekstrak daun putri malu terhadap larva Aedes aegypti. Hasil analisis dapat dilihat pada Tabel 3 berikut.

Berdasarkan hasil analisis probit tersebut didapatkan $\mathrm{LC}_{50}$ ekstrak daun putri malu adalah $14,568 \mathrm{mg} / \mathrm{ml}$. 
Tabel 3. Hasil analisis probit LC 50 ekstrak daun putri malu (Mimosa pudica Linn) terhadap mortalitas larva nyamuk Aedes aegypti

\begin{tabular}{cccc}
\hline $\begin{array}{c}\text { Persentase } \\
\text { Kematian } \\
(\%)\end{array}$ & $\begin{array}{c}\text { Konsentrasi } \\
\text { Ekstrak Daun } \\
\text { Putri Malu } \\
(\mathbf{m g} / \mathbf{m l})\end{array}$ & $\begin{array}{c}\text { Batas } \\
\text { Bawah } \\
(\%)\end{array}$ & $\begin{array}{c}\text { Batas } \\
\text { Atas (\%) }\end{array}$ \\
\hline 10 & 11,225 & 5,461 & 12,750 \\
30 & 13,094 & 9,287 & 14,095 \\
50 & 14,568 & 12,948 & 15,652 \\
70 & 16,208 & 15,203 & 20,642 \\
90 & 18,907 & 16,925 & 34,856 \\
\hline
\end{tabular}

\section{PEMBAHASAN}

Proses ekstraksi dilakukan di Laboratorium Farmasi Unand. Ekstrak daun putri malu diproses dengan metode maserasi menggunakan 300 gram simplisia daun putri malu yang di rendam dalam 3 liter pelarut etanol $96 \%$ dan menggunakan perbandingan 1:10 b/v. Selama proses ekstraksi dilakukan pengadukan berulang-ulang dengan tujuan agar memudahkan pelarut untuk melarutkan senyawa kimia yang ingin diisolasi dari dalam sel tumbuhan. ${ }^{15}$ Ekstrak direndam selama 2-3 hari kemudian dilakukan pemekatan menggunakan Rotary Evaporator.

Hasil ekstrak yang didapatkan adalah sebanyak 45 gram ekstrak kental yang merupakan 15\% dari total berat simplisia. Hal tersebut berbeda dengan penelitian yang dilakukan oleh Fadlian et al dimana hasil ekstraksi tanaman putri malu dari 200 gram sampel menghasilkan 20,1 gram ekstrak yang merupakan 10,05\% dari total berat simplisia. ${ }^{16}$

Perbedaan persentase hasil ekstraksi pada penelitian tersebut mungkin dipengaruhi oleh banyaknya pelarut yang digunakan dalam proses ekstraksi. Pada penelitian Fadlian et al pada tahun 2016 menggunakan pelarut etanol dengan perbandingan $1: 3 \mathrm{~b} / \mathrm{v}$ sedangkan pada penelitian ini menggunakan perbandingan $1: 10 \mathrm{~b} / \mathrm{v}$ dan dihasilkan persentase hasil ekstraksi yang lebih banyak. ${ }^{16}$

Berdasarkan hasil pengamatan jumlah kematian larva Aedes aegypti setelah 24 jam pemaparan ekstrak daun putri malu pada tabel 1 tidak dijumpai kematian larva pada konsentrasi 1, 2, 3, 4, dan $5 \mathrm{mg} / \mathrm{ml}$. Hal ini menunjukan bahwa serial konsentrasi tersebut tidak efektif membunuh larva Aedes aegypti sehingga dilakukan pengujian dengan konsentrasi yang lebih tinggi seperti pada Tabel 2.

Hasil pengamatan pada Tabel 2 didapatkan bahwa pada konsentrasi 10, 12,5 dan $15 \mathrm{mg} / \mathrm{ml}$ ditemukan persentase kematian larva pada masingmasing konsentrasi ekstrak tersebut sebesar 12,5, 30 dan $60 \%$. Hal ini menunjukkan bahwa konsentrasi ekstrak daun putri malu pada 10, 12,5 dan $15 \mathrm{mg} / \mathrm{ml}$ dapat dikatakan efektif dalam membunuh larva Aedes aegypti. Berdasarkan WHO, larvasida dikatakan efektif apabila dapat membunuh $10-95 \%$ larva uji. ${ }^{17}$

Pengujian dengan larutan kontrol akuades tidak menyebabkan kematian pada larva uji, hal ini menunjukkan bahwa larutan kontrol (akuades) yang digunakan tidak mempengaruhi hasil pada kelompok pemaparan ekstrak daun putri malu dan membuktikan bahwa terdapat pengaruh pemberian ekstrak daun putri malu terhadap kematian larva Aedes aegypti.

Mekanisme kerja ekstrak daun putri malu sebagai larvasida sesuai dengan kandungan yang terdapat pada ekstrak tersebut. Daun putri malu diketahui mengandung beberapa senyawa aktif dari golongan polifenol yaitu flavonoid, tanin, saponin dan alkaloid. ${ }^{5}$ Masing-masing senyawa tersebut memiliki mekanisme yang berbeda-beda dalam membunuh larva.

Metabolit sekunder tanaman yang masuk ke dalam tumbuh larva akan berpotensi sebagai zat racun dengan efek yang relatif tidak spesifik pada beberapa sasaran molekuler. Target-target molekuler yang dimaksud berupa protein (enzim, reseptor, molekul pensinyalan, ion-channels, dan protein struktural), asam nukleat, biomembran dan komponen seluler lainnya. Hal terebut dapat mempengaruhi fisiologi larva dalam berbagai cara dan di berbagai lokasi reseptor, yang paling utama adalah pada sistem saraf (dalam sintesis neurotransmitter, penyimpanan, pelepasan, pengikatan, pengambilan kembali, aktivasi dan fungsi reseptor), enzim yang terlibat dalam jalur transduksi sinyal. ${ }^{17}$

Kandungan senyawa flavonoid tersebut dapat mempengaruhi proses metabolisme larva dengan cara merusak permeabilitas dinding sel, dan menghambat kerja enzim. ${ }^{18}$ Apabila larva menyerap flavonoid dan masuk ke dalam darah, maka larva akan kekurangan oksigen. ${ }^{8}$ Tanin dapat merusak dinding sel, 
menggumpalkan protein, serta memiliki rasa pahit sehingga menghambat larva untuk memakannya. ${ }^{19,20}$

Saponin merupakan senyawa glikosida yang bersifat racun sehingga larva yang terpapar glikosida akan merasakan pahit, selain itu juga dapat bersifat hemolisis yang dapat menghancurkan sel darah. Senyawa glikosida akan bereaksi dengan oksigen yang terdapat pada tubuh larva sehingga menghasilkan air dan gugus fungsional yang merupakan racun yang dapat menyerang tubuh larva. Alkaloid yang masuk ke dalam tubuh akan mempengaruhi kerja otak. $^{8}$

Nilai Lethal Concentration 50\% ditentukan berdasarkan analisis probit. Hasil analisis probit didapatkan nilai LC $_{50}$ adalah $14,568 \mathrm{mg} / \mathrm{ml}$, artinya bahwa pada konsentrasi ekstrak daun putri malu tersebut dapat membunuh $50 \%$ dari total larva uji.

Penelitian sebelumnya pada tahun 2015 yang telah dilakukan oleh Fitria dan Amilah didapatkan hasil bahwa konsentrasi letal $\left(\mathrm{LC}_{50}\right)$ ekstrak daun putri malu yang dapat mematikan larva Aedes aegypti adalah 3,25 g/l. Hasil penelitian tersebut menunjukkan bahwa nilai $\mathrm{LC}_{50}$ pada penelitian yang dilakukan oleh Fitria $E$ dan Amilah $S$ tersebut lebih rendah dibandingkan penelitian ini. ${ }^{8}$

Penelitian lainnya yang dilakukan oleh Astalakshmi et al pada tahun 2016 dengan menggunakan tumbuhan putri malu yang berasal dari kota Chelembra, India didapatkan hasil bahwa ekstrak daun putri malu yang digunakan pada penelitian tersebut tidak efektif sebagai larvasida terhadap larva nyamuk Aedes aegypty sehingga $\mathrm{LC}_{50}$ pada penelitian tersebut tidak dapat ditentukan. ${ }^{9}$

Perbedaan hasil antara penelitian yang dilakukan dengan penelitian lainnya tersebut mungkin dapat dipengaruhi oleh beberapa faktor seperti variasi geografi, metode ekstraksi, dan pelarut yang digunakan. $^{21}$

Perbedaan penelitian ini terhadap penelitian Fitria dan Amilah serta Astalakshmi et al dimungkinkan karena perbedaan tempat tumbuhnya tumbuhan putri malu (Mimosa pudica L). Penelitian ini menggunakan tumbuhan yang berasal dari Padang, sedangkan penelitian Fitria dan Amilah berasal dari Surabaya, dan penelitian Astalakshmi et al berasal dari India. ${ }^{8,9}$ Perbedaan tempat tumbuhan tersebut merupakan suatu faktor ekologi yang mungkin dapat mempengaruhi secara signifikan terhadap konsentrasi bahan aktif tumbuhan tersebut.

Faktor ekologi utama yang mempengaruhi konsentrasi bahan aktif tersebut adalah suhu, curah hujan, durasi sinar matahari, $\mathrm{pH}$ tanah, bahan organik dan kalium yang tersedia di suatu tempat. ${ }^{10} \mathrm{Hal}$ tersebut dapat menyebabkan aktivitas farmakologi yang dihasilkan berbeda-beda sehingga hasil penelitian yang didapatkan dari spesies tumbuhan yang sama juga dapat berbeda-beda.

Tumbuhan putri malu membutuhkan kondisi lingkungan yang sesuai agar dapat tumbuh dengan baik. Tumbuhan ini dapat tumbuh di daerah yang beriklim tropis seperti Indonesia, sedangkan India tak hanya memiliki iklim tropis namun juga iklim subtropis. Tumbuhan putri malu biasanya tumbuh merambat atau berbentuk seperti semak dengan tinggi antara 0,3-1,5 $\mathrm{m}$ dan tumbuh liar di pinggir jalan atau di tempattempat terbuka yang terkena sinar matahari. ${ }^{22}$

Hal ini sesuai dengan hasil penelitian Astalakshmi et al dengan tanaman putri malu yang berasal dari India dan didapatkan bahwa tanaman tersebut tidak efektif sebagai larvasida, mungkin hal tersebut karena habitat daun putri malu yang kurang baik di India sehingga aktivitas farmakologi yang dihasilkannya juga kurang optimal. ${ }^{9}$

Perbedaan hasil penelitian tersebut mungkin juga dapat disebabkan karena perbedaan pelarut yang digunakan saat proses ekstraksi. Pada penelitian ini dan Fitria dan Amilah menggunakan pelarut etanol 96\%, sedangkan pada penelitian Astalakshmi et al menggunakan pelarut air atau akuades. ${ }^{8,9}$

Hal tersebut sesuai dengan hasil penelitian Thongwat et al pada tahun 2017 yang membandingkan efektivitas larvasida ekstrak tumbuhan Dracaena loureirin (bambu rezeki) yang menggunakan pelarut etanol dan air. Berdasarkan penelitian tersebut didapatkan hasil bahwa ekstrak yang menggunakan pelarut etanol memiliki efek larvasida yang kuat secara signifikan dibandingkan pelarut air. $^{23}$ 


\section{SIMPULAN}

Ekstrak daun putri malu (Mimosa pudcia Linn.) yang tumbuh di Padang memiliki potensi sebagai larvasida nabati terhadap kematian larva nyamuk Aedes aegypti instar III/IV dengan nilai Lethal Concentration $50 \%\left(\mathrm{LC}_{50}\right)$ adalah sebesar 14,568 $\mathrm{mg} / \mathrm{ml}$.

\section{SARAN}

Penelitian selanjutnya disarankan untuk melakukan peneliitian lebih lanjut terkait pemanfaatan ekstrak daun putri malu sebagai larvasida nabati dengan mengisolasi senyawa-senyawa aktif beserta uji aktivitas masing-masing senyawa aktif tersebut sehingga dapat diketahui senyawa apakah yang lebih dominan sebagai larvasida.

\section{UCAPAN TERIMA KASIH}

Terima kasih kepada Bagian Parasitologi Fakultas Kedokteran Universitas Andalas serta seluruh pihak yang telah memberikan dukungan serta bimbingan dalam menyelesaikan penelitian ini.

\section{DAFTAR PUSTAKA}

1. World Health Organization (WHO). Dengue Guidelines for Diagnosis, Treatment, Prevention and Control: New Edition. 2009 (diunduh September 2018). Tersedia dari: https://apps.who.int/iris/handle/10665/44188

2. Dinas Kesehatan Provinsi Sumatera Barat. Profil Kesehatan Provinsi Sumatera Barat 2015. Padang: Dinas Kesehatan Provinsi Sumatera Barat; 2016.

3. WHO. The mosquito. 2018. Geneva: World Health Organization.(diunduh Agustus 2018). Tersedia dari: http://www.who.int/denguecontrol/ mosquito/ en/.rah

4. Rafikov M, Rafikova E, Yang HM. Optimization of the Aedes aegypti control strategies for integrated vector management. Journal of Applied Mathematics. 2015.(diunduh September 2018). Tersedia dari: http://dx.doi.org/10.1155/2015/ 918194

5. Paul S, Saha D, Chowdury S. Pharmacognostic studies on aerial Part of Mimosa pudica. Asian $\mathrm{J}$ Pharm Tech. 2012;2(3):101-3.
6. Lakshmibai R, Amirtham D, Radgika S. Preliminary phytochemical analysis and antioxidant activities of prosopis juliflora and Mimosa pudica Leaves. Int $\mathrm{J}$ Sci Eng Technol Res. 2015;4(30):5766-70.

7. Zhang J, Yuan K, Zhou WL, Zhou J, Yang P. Studies on the active components and antioxidant activities of the extracts of Mimosa pudica Linn, from Southern China. Pharmacogn Mag. $2011 ; 7(25): 35-9$.

8. Fitria E, Amilah S. LC50 dari ekstrak daun putri malu (Mimosa pudica L.) terhadap larva nyamuk demam berdarah (Aedes aegypti L.) dan Larva nyamuk malaria (Anopheles sp.). STIGMA: Jurnal Matematika dan Ilmu Pengetahuan Alam Unipa. 2015;8(1):5-8.

9. Astalakshmi N, Surendra KM, Akshaya M, Irfana $\mathrm{CP}$, Rajpriya U, Babu G, et al. Evaluation of Mimosa pudica and Dioscorea alata Linn for its larvicidal activity. World J Pharm Pharm Sci. 2016; 5(7):1967-70.

10. Liu W, Liu J, Yin D, Zhao X. Influence of Ecological Factors on The Production of Active Substances in The Anti-Cancer Plant Sinopodophyllum hexandrum (Royle) T.S. Ying. PLoS One. 2015;10 (4):1-22.

11.WHO. Monitoring and managing insecticide resistance in Aedes mosquito populations. 2016.(diunduh September 2018). Tersedia dari: http://who.int/csr/resources/publications/zika/insecti cide-resistance/en/

12. Nofita E, Hasmiwati, Rusdji SR, Irawati N. Analysis of indicators entomology Aedes aegypti in endemic areas of dengue fever in Padang, West Sumatra, Indonesia. Int J Mosq Res. 2017;4(2): 57-9.

13. Pusarawati S, Ideham B, Kusmartisnawati, Tantular I, Basuki S. Atlas parasitologi kedokteran. Jakarta: Penerbit Buku Kedokteran EGC; 2017.hlm.118-120.

14. Sukamsih. Perbedaan berbagai $\mathrm{pH}$ Air terhadap kehidupan larva nyamuk Aedes aegypti di laboratorium balai besar penelitian vektor dan reservoir penyakit salatiga tahun 2005 [skripsi]. Fakultas Kesehatan Masyarakat, Universitas Diponegoro. Semarang; 2006. 
15. Braja M. Uji Toksisitas ekstrak daun Ficus elastica Nois ex Blume terhadap artemia salina leach dan profil kromatografi lapis tipis [skripsi]. Fakultas Farmasi, Universitas Muhammadiyah. Surakarta; 2008.

16. Fadlian F, Hamzah B, Abram PH. Uji Efektivitas Ekstrak Tanaman Putri Malu (Mimosa pudica Linn) sebagai Bahan Pengawet Alami Tomat. Jurnal Akademika Kimia. 2016;5(4):153-8.

17. WHO. Guideline for laboratory and field testing of mosquito larvicides. 2005.(diunduh Januari 2019). Tersedia dari: http://apps.who.int/iris/ bitstream/handle/10665/69101/WHO CDS WHOP ES GCDPP 2005.13.pdf

18. Aseptianova, Wijayanti TF, Nuraini N. Efektifitas pemanfaatan tanaman sebagai insektisida elektrik untuk mengendalikan nyamuk penular penyakit DBD. Bioeksperimen. 2017;3(2):10-9.

19. Fahriya PS, Muktiana SS. Ekstraksi zat aktif antimikroba dari tanaman yodium (Jatropha multifida Linn) sebagai bahan baku alternatif antibiotik alami. 2012.(diunduh Desember 2018). Tersedia dari: http://eprints.undip.ac.id/36753/

20. Yunita EA, Suprapti NH, Hidayat JS. Ekstrak daun teklan (Eupatorium riparium) terhadap mortalitas dan perkembangan larva Aedes aegypti. Bioma. 2009;11(1):11-7.

21. Ghosh A, Chowdhury N, Chandra G. Plant extract as potential mosquito larvicides. Indian J Med Res. 2012;135(5):581-98.

22. Faridah J. Putri Malu. 2007.(diunduh Januari 2019). Tersedia dari: http://eprints. undip.ac.id/view/year/2009.html

23. Thongwat D, Lamlertthon S, Pimolsri U, Bunchu N. Larvicidal activity of endocarp and seed crude extracts of Dracaena loureirin Gagnep against Aedes aegypti (L.) Mosquito. Asian Pac Trop Biomed. 2017;7(3):222-6. 